\title{
Lactation performance of dairy cows fed increasing concentrations of wheat dried distillers grains with solubles
}

\author{
M. M. Abdelqader and M. Oba ${ }^{1}$ \\ Department of Agricultural, Food and Nutritional Science, University of Alberta, Edmonton, AB, T6G 2P5, Canada
}

\begin{abstract}
In Western Canada, dried distillers grains with solubles (DDGS) is produced from mixtures of corn and wheat at variable ratios, and used as a source of dietary crude protein $(\mathrm{CP})$ in diets of lactating dairy cows. The objective of this study was to determine the effect of increasing dietary allocation of wheat DDGS on dry matter intake, milk production, milk composition, feed efficiency, plasma metabolites, and ruminal fermentation of dairy cows in midlactation. Sixteen multiparous and 16 primiparous lactating Holstein cows were used in a replicated $4 \times 4$ Latin square design with 3 -wk periods. Dietary treatments were a control diet containing canola meal as the primary protein source $(\mathrm{CON})$ and diets containing increasing concentrations of wheat DDGS in place of corn DDGS $(0,50$, and $100 \%$ of dietary DDGS allocation). The treatment protein sources supplied approximately 35\% of dietary CP. Yields of milk, milk fat, lactose, and energy-corrected milk were greater for diets containing DDGS compared with the CON diet. Although cows fed the DDGS diets tended to have lower CP digestibility compared with those fed the CON diet, concentrations of ruminal ammonia nitrogen, plasma urea nitrogen, and milk urea nitrogen were higher, but milk protein concentration was lower for cows fed the DDGS diets. Although dry matter intake increased linearly as the dietary allocation of wheat DDGS increased, milk yield was not affected, thus decreasing feed efficiency linearly. Feeding increasing levels of wheat DDGS tended to decrease plasma glucose concentration linearly. Plasma Leu concentration decreased linearly and plasma Gln concentration increased linearly as dietary inclusion of wheat DDGS increased. Apparent total-tract digestibility of nutrients except for CP was not affected by dietary treatments. A mixture of wheat and corn DDGS seems to have similar feeding values to both DDGS sources and it can be used as an alternative protein source in diets for
\end{abstract}

Received August 8, 2011.

Accepted March 16, 2012.

${ }^{1}$ Corresponding author: moba@ualberta.ca lactating dairy cows. However, replacing corn DDGS with wheat DDGS might decrease feed efficiency.

Key words: corn dried distillers grains with solubles, wheat dried distillers grains with solubles, feed efficiency

\section{INTRODUCTION}

Byproducts from ethanol production are widely used as feedstuffs in diets of dairy cattle. Although corn is the most common grain used in ethanol production, other grains such as wheat, barley, and triticale can be used for ethanol production (Mustafa et al., 2000). Grains used as fermentation substrate can vary according to market price and local availability. In the United States, corn is the primary grain used in ethanol production due to its consistent availability. Alternatively, in Western Canada, ethanol is predominantly produced from wheat grain, as it is more readily available than corn. However, a mixture of corn and wheat at different proportions are often used for ethanol production, depending on market price and availability of both grains, which makes dried distillers grains with solubles (DDGS) produced in Western Canada unique. As wheat DDGS from Western Canada is also extensively used by the dairy industry in the Western United States, its feeding values are of great interest in the US dairy industry as well as in Canada.

Corn DDGS are high in energy and protein contents, but lower in starch content compared with the original grain sources (NRC, 2001). In addition, corn DDGS are considered an excellent source of RUP (Firkins et al., 1984; Powers et al., 1995) and highly digestible fiber (Al-Suwaiegh et al., 2002). However, the nutritional characteristics of DDGS can vary greatly among and within grain sources. Wheat DDGS typically contains greater content of protein (approximately 40 vs. 30\%) and significantly lower content of oil (approximately 5 vs. 10\%) compared with corn DDGS (Gibb et al., 2008). The difference in CP content between wheat and corn DDGS is attributed to the greater CP content of wheat grain relative to corn grain. Consequently, the CP content of DDGS derived from both grains increases as the wheat-to-corn ratio increases in the grain mix (Boila 
and Ingalls, 1994). Several studies have reported a large variation in the RUP values for corn DDGS, which can range from 40.0 to $76.0 \%$ of CP (Ingalls, 1995; Kleinschmit et al., 2007; Cao et al., 2009). Although the data for RUP of wheat DDGS is limited, it was shown to range from 51.3 to $59.5 \%$ of CP (Mustafa et al., 2000; Gibb et al., 2008). Several studies that evaluated the protein quality of corn DDGS indicated that it can be used to improve productivity of lactating cows when included up to $20 \%$ of dietary DM (Anderson et al., 2006; Schingoethe et al., 2009).

The majority of the studies conducted on wheat DDGS for dairy cows evaluated its feeding values in partial replacement of forages or grains. Penner et al. (2009) evaluated wet wheat-based distillers grain as a partial replacement of forage in dairy cow rations. Wet distillers grains were included in the ration at $10 \%$ of diet DM. They showed that feeding wet wheat distillers grain as a forage substitute increased milk yield by $7 \%$ and milk protein content by $9 \%$. Even though milk fat yield was not affected, milk fat concentration was decreased (3.04 vs. $3.36 \%$ ) for cows fed wet wheat distillers grains compared with those fed the control diet. Recently, Zhang et al. (2010b) reported that feeding corn/wheat-based distillers grains in partial replacement of barley grain had no negative effect on dairy cow production. Zhang et al. (2010a) further evaluated the effect of feeding wheat DDGS as a partial replacement of barley silage with or without alfalfa hay, and reported that feeding wheat DDGS as a substitute for barley silage can improve dairy cow production. However, it may decrease chewing time, ruminal $\mathrm{pH}$, and milk fat concentration.

Although several studies have been conducted to compare the feeding value of wheat DDGS with corn DDGS in beef cattle (Aldai et al., 2010; Walter et al., 2010) and sheep (McKeown et al., 2010), a scarcity of data exists comparing the feeding value of wheat DDGS, corn DDGS, and their mixture as a protein source in diets of lactating dairy cows. As such, the objective of this study was to determine the effect of feeding DDGS from wheat and corn at different proportions on performance of lactating dairy cows.

\section{MATERIALS AND METHODS}

\section{Animals and Diets}

Sixteen multiparous and 16 primiparous lactating Holstein cows $(\mathrm{DIM}=127 \pm 67$ and $\mathrm{BW}=615 \pm 73$ $\mathrm{kg}$; mean $\pm \mathrm{SD}$ ) were used in a replicated $4 \times 4$ Latin square design balanced for carryover effects with 3 -wk periods. The first 2 wk were used for diet adaptation and the last week was used for sampling and data col- lection. Dietary treatments were a control diet containing canola meal as the primary protein source $(\mathbf{C O N})$ and diets containing corn DDGS at $20 \%$ of diet DM, a 50:50 mixture of corn and wheat DDGS, and wheat DDGS at $15 \%$ of DM. The chemical composition of corn DDGS and wheat DDGS is shown in Table 1. The treatment protein sources supplied $35 \%$ of dietary CP. All diets contained 40:60 forage-to-concentrate ratio, where forage consisted of barley silage (Table 2). Dietary treatments were formulated to meet or exceed NRC nutrient requirements (NRC, 2001) for cows producing $40 \mathrm{~kg}$ of milk/d at $24 \mathrm{~kg}$ of DMI/d. All diets were formulated to contain similar RDP, RUP, MP, fat, $\mathrm{NDF}, \mathrm{NFC}$, and $\mathrm{NE}_{\mathrm{L}}$ contents. Cows were housed in a tie-stall barn and individually fed once daily (0730 h) for ad libitum intake. Amounts of feed offered and refused were recorded daily, and adjusted to allow for 5 to $10 \%$ refusal. Cows were milked twice daily at 0600 and $1600 \mathrm{~h}$, and milk yield was recorded at each milking. Eight multiparous cows were ruminally cannulated (in a 2 Latin square design), and used to determine the treatment effects on ruminal fermentation and totaltract nutrient digestibility.

\section{Sampling and Chemical Analysis}

Samples of barley silage, concentrates, and TMR were collected weekly. Barley silage and diet samples were stored at $-20^{\circ} \mathrm{C}$ until analysis. Concentrate samples were stored at room temperature. Feed samples were made into composites by period and dried at $55^{\circ} \mathrm{C}$ in a forced-air oven (V-31 STD, Style II; Despatch Industries Inc., Nashua, Mississauga, ON, Canada) for $48 \mathrm{~h}$ and then ground through a 1-mm screen using a Wiley Mill (model 3; Arthur H. Thomas Co., Philadelphia, PA). Subsamples of feed composites were dried at $135^{\circ} \mathrm{C}$ for $2 \mathrm{~h}$ to determine DM content (AOAC, 2002; method 930.15). Composites were analyzed according to the Association of Official Analytical Chemists (AOAC, 2002) for CP (method 2001.11), ether extract (method 920.39), and ash (method 942.05). Feed samples were analyzed for NDF concentration using heat-stable $\alpha$-amylase and sodium sulfite (Van Soest et al., 1991). The starch contents were determined by an enzymatic method (Karkalas, 1985) after samples were gelatinized with sodium hydroxide. Glucose was measured using a glucose oxidase/peroxidase enzyme (No. P7119; Sigma, St. Louis, MO) and dianisidine dihydrochloride (no. F5803; Sigma), and sample absorbance was determined with a plate reader (SpectraMax 190; Molecular Devices Corp., Sunnyvale, CA). Ether extract concentrations were determined using a Goldfisch extraction apparatus with petroleum ether (Labconco Corp., Kansas City, MO). Both wheat and corn DDGS 
Table 1. Chemical composition of corn and wheat dried distillers grains with solubles

\begin{tabular}{|c|c|c|}
\hline \multirow[b]{2}{*}{ Composition } & \multicolumn{2}{|c|}{ Distillers grains } \\
\hline & Corn & Wheat \\
\hline DM & 86.0 & 88.4 \\
\hline \multicolumn{3}{|l|}{$\%$ of DM } \\
\hline NDF & 31.9 & 25.7 \\
\hline Ether extract & 10.5 & 4.5 \\
\hline $\mathrm{NFC}^{1}$ & 21.2 & 20.2 \\
\hline Ash & 4.4 & 5.3 \\
\hline $\mathrm{CP}$ & 32.0 & 44.3 \\
\hline $\mathrm{TDN}^{2}$ & 83.8 & 75.9 \\
\hline \multicolumn{3}{|l|}{$\mathrm{AA}, \%$ of $\mathrm{CP}$} \\
\hline Total EAA ${ }^{3}$ & 41.4 & 29.4 \\
\hline His & 2.56 & 1.67 \\
\hline Met & 2.00 & 1.42 \\
\hline Lys & 3.20 & 2.17 \\
\hline Leu & 11.59 & 5.79 \\
\hline Ile & 3.78 & 3.21 \\
\hline Val & 5.20 & 4.10 \\
\hline $\operatorname{Arg}$ & 4.25 & 3.87 \\
\hline Thr & 3.66 & 2.49 \\
\hline Trp & 0.69 & 0.72 \\
\hline Phe & 4.50 & 3.91 \\
\hline Total NEAA ${ }^{4}$ & 45.4 & 45.7 \\
\hline Ala & 7.06 & 3.57 \\
\hline Asp & 6.31 & 4.25 \\
\hline Gln & 13.47 & 20.70 \\
\hline Ser & 4.38 & 3.37 \\
\hline Gly & 3.88 & 3.66 \\
\hline Tau & 0.09 & 0.05 \\
\hline Tyr & 3.13 & 2.37 \\
\hline Orn & 0.06 & 0.09 \\
\hline Pro & 7.06 & 7.68 \\
\hline
\end{tabular}

${ }^{1} \mathrm{NFC}=100-(\% \mathrm{NDF}+\% \mathrm{CP}+\%$ ether extract $+\%$ ash $)$.

${ }^{2}$ Calculated according to NRC (2001).

${ }^{3} \mathrm{EAA}=$ essential AA.

${ }^{4} \mathrm{NEAA}=$ nonessential AA.

samples were analyzed for AA profile according to the method described by Kim et al. (2006).

Milk samples from both milkings were collected on d 18,19 , and 21 of each period, and sent to the Alberta Central Milk Testing Laboratory for compositional analysis, where fat, true protein, MUN, and lactose concentrations were determined using mid-infrared spectroscopy (MilkoScan 605; Foss North America, Brampton, Ontario, Canada; method 972.16; AOAC, 2002).

Blood samples were collected during the last week of each period at $1900 \mathrm{~h}$ on d 17, $0100 \mathrm{~h}$ on d 19, 0700 $\mathrm{h}$ on $\mathrm{d} 20$, and $1300 \mathrm{~h}$ on $\mathrm{d} 21$ from the coccygeal vein into evacuated tubes containing sodium heparin (Fisher Scientific Co., Nepean, Ontario, Canada) and immediately placed on ice until centrifugation at 2,500 $\times g$ for $20 \mathrm{~min}$ at $4^{\circ} \mathrm{C}$, then plasma was harvested and stored at $-20^{\circ} \mathrm{C}$ until further processing. At the end of each period plasma was thawed and composited by cow and period, and stored at $-20^{\circ} \mathrm{C}$ until further analysis.
Plasma glucose concentration was measured using a glucose oxidase-peroxidase enzyme (no. P7119; Sigma) and dianisidine dihydrochloride (no. F5803; Sigma). Absorbance was determined with a plate reader (SpectraMax 190; Molecular Devices Corp.). Plasma insulin concentration was determined using a commercial kit (Coat-A-Count; Diagnostic Products Corp., Los Angeles, CA). The concentration of plasma urea $\mathrm{N}$ was determined following the procedure of Fawcett and Scott (1960) with modifications for use of a plate reader.

Ruminal $\mathrm{pH}$ was measured every $30 \mathrm{~s}$ for $96 \mathrm{~h}$ using the LRC ruminal $\mathrm{pH}$ data logger system (Dascor, Escondido, CA) and summarized as described in detail by Penner et al. (2006). The data logger was placed in the rumen on d 17 and removed on d 21 of each period. Ruminal fluid was collected every $10 \mathrm{~h}$ over a 5 -d period to account for diurnal variation (at 0800 and $1800 \mathrm{~h}$ on d 17; at 0400,1400 , and $2400 \mathrm{~h}$ on d 18 ; at 1000 and $2000 \mathrm{~h}$ on d 19 ; at 0600 and $1600 \mathrm{~h}$ on d 20; and at 0200,1200 , and $2200 \mathrm{~h}$ on d 21). Ruminal digesta were collected in equal proportions from the cranial dorsal, cranial ventral, central, caudal dorsal, and caudal ventral regions. Ruminal fluid was strained through a perforated screen (Petex, pore size $=355$ $\mu \mathrm{m}$; Sefar Canada Inc., Scarborough, Canada) and a subsample of $10 \mathrm{~mL}$ was obtained for each cow and placed on ice immediately after collection. The ruminal fluid filtrates were centrifuged at $3,000 \times g$ at $4^{\circ} \mathrm{C}$ for 20 min. Samples were composited per cow for each period, and stored at $-20^{\circ} \mathrm{C}$ until analysis.

Ruminal fluid samples were thawed and centrifuged at $26,000 \times g$ for $15 \mathrm{~min}$ at $4^{\circ} \mathrm{C}$. The centrifuged supernatant was analyzed for VFA concentration according to the method described by Khorasani et al. (1996) with some modifications. Concentrations of VFA were determined by gas chromatography in a chromatograph equipped with a flame ionization detector and an autoinjector (model 8200; Varian Inc., Walnut Creek, CA). Volatile fatty acids were separated using a StabilwaxDA column $(30-\mathrm{m} \times 0.53-\mathrm{mm}$ i.d. $\times 0.5-\mu \mathrm{m}$ film $)$ on a Varian GC (model 3400; Varian Inc.). The split ratio at the injector port was set at 20:1 with a column temperature of 90 to $170^{\circ} \mathrm{C}$ with an increase of $10^{\circ} \mathrm{C} /$ min followed by a 2-min hold. The injector and detector temperatures were 170 and $190^{\circ} \mathrm{C}$, respectively. Peak integration was performed using Galaxie software (Varian Inc.). Ruminal $\mathrm{NH}_{3}-\mathrm{N}$ concentration was determined colorimetrically as described by Fawcett and Scott (1960).

Fecal samples were collected every $10 \mathrm{~h}$ over a 5 -d period (at 0800 and $1800 \mathrm{~h}$ on d 17; at 0400, 1400, and $2400 \mathrm{~h}$ on d 18; at 1000 and $2000 \mathrm{~h}$ on d 19; at 0600 and $1600 \mathrm{~h}$ on d 20; and at 0200,1200 , and $2200 \mathrm{~h}$ on d 21). At each sampling time, $100 \mathrm{~g}$ of feces was collected and 
Table 2. Ingredients and chemical composition of experimental diets

\begin{tabular}{|c|c|c|c|c|}
\hline \multirow[b]{2}{*}{ Composition } & \multicolumn{4}{|c|}{ Dietary treatment ${ }^{1}$} \\
\hline & $\mathrm{CON}$ & WDG0 & WDG50 & WDG100 \\
\hline \multicolumn{5}{|l|}{ Ingredient, $\%$ of DM } \\
\hline Barley silage & 40.0 & 40.0 & 40.0 & 40.0 \\
\hline Rolled barley grain & 16.5 & 16.5 & 16.5 & 16.5 \\
\hline Rolled corn grain & 16.5 & 16.5 & 16.5 & 16.5 \\
\hline Canola meal & 10.2 & 0.0 & 0.0 & 0.0 \\
\hline Wheat DDGS & 0.0 & 0.0 & 8.75 & 15.0 \\
\hline Corn DDGS & 0.0 & 20.0 & 8.75 & 0.0 \\
\hline Beet pulp dried & 8.0 & 3.1 & 5.0 & 6.75 \\
\hline Corn gluten meal & 4.65 & 0.70 & 0.85 & 1.15 \\
\hline Vegetable oil & 1.25 & 0.0 & 0.62 & 1.20 \\
\hline Urea & 0.09 & 0.40 & 0.23 & 0.10 \\
\hline Premix $^{2}$ & 1.15 & 1.15 & 1.15 & 1.15 \\
\hline Limestone & 1.10 & 1.10 & 1.10 & 1.10 \\
\hline Salt & 0.40 & 0.40 & 0.40 & 0.40 \\
\hline Magnesium oxide & 0.15 & 0.15 & 0.15 & 0.15 \\
\hline \multicolumn{5}{|l|}{ Chemical composition } \\
\hline DM, $\%$ & 56.1 & 59.4 & 56.5 & 55.1 \\
\hline $\mathrm{OM}, \%$ of $\mathrm{DM}$ & 90.0 & 93.3 & 91.4 & 92.0 \\
\hline $\mathrm{CP}, \%$ of DM & 21.4 & 18.5 & 21.4 & 20.7 \\
\hline Lys, ${ }^{3} \%$ of MP & 5.61 & 5.51 & 5.36 & 5.19 \\
\hline $\operatorname{Met}_{3}^{3} \%$ of MP & 1.92 & 1.91 & 1.83 & 1.80 \\
\hline His, ${ }^{3} \%$ of MP & 2.08 & 2.12 & 2.02 & 1.93 \\
\hline Lys:Met ratio & 2.92 & 2.88 & 2.93 & 2.88 \\
\hline $\mathrm{NDF}, \%$ of DM & 28.8 & 29.6 & 29.4 & 28.7 \\
\hline Starch, \% of DM & 23.9 & 29.8 & 22.7 & 23.9 \\
\hline $\mathrm{EE}, \%$ of DM & 3.8 & 3.4 & 3.5 & 3.6 \\
\hline
\end{tabular}

${ }^{1} \mathrm{CON}=$ control diet containing canola meal as the primary protein source; WDG0 $=$ diet containing corn dried distillers grains with solubles (DDGS) at 20\% of diet DM; WDG50 = diet containing $50 \%$ corn DDGS and $50 \%$ wheat DDGS; WDG100 = diet containing wheat DDGS at $15 \%$ of DM.

${ }^{2}$ Contained $0.10 \% \mathrm{Ca}, 0.60 \% \mathrm{P}, 11.5 \% \mathrm{Na}, 0.30 \% \mathrm{Mg}, 10 \mathrm{mg}$ of $\mathrm{Fe} / \mathrm{kg}, 1,170 \mathrm{mg}$ of $\mathrm{Cu} / \mathrm{kg}, 6.2 \mathrm{mg}$ of $\mathrm{Co} / \mathrm{kg}$, $31,000 \mathrm{mg}$ of $\mathrm{Mn} / \mathrm{kg}, 5,000 \mathrm{mg}$ of $\mathrm{Zn} / \mathrm{kg}, 80 \mathrm{mg}$ of I/ kg, 1,265,000 IU of vitamin A/kg, 142,000 IU of vitamin $\mathrm{D} / \mathrm{kg}$, and $3,800 \mathrm{IU}$ of vitamin $\mathrm{E} / \mathrm{kg}$.

${ }^{3}$ Calculated using the NRC (2001).

stored in one container at $-20^{\circ} \mathrm{C}$ until the end of the collection period. Fecal composites were freeze dried and analyzed for DM, OM, CP, ether extract, starch, $\mathrm{NDF}$, and indigestible NDF content. Indigestible NDF content was analyzed by 120-h in situ incubation and used as an internal marker to estimate apparent totaltract nutrient digestibility (Cochran et al., 1986).

Cows were weighed and BCS ( 1 to $5 ; 1=$ thin and 5 = obese) was determined on 2 consecutive days at the beginning of the first period and at the end of each experimental period. Energy values and empty BW were calculated according to NRC (2001) as described by Abdelqader et al. (2009b).

\section{Statistical Analysis}

Data were analyzed as a replicated $4 \times 4$ Latin square using the MIXED procedure of SAS (version 9.1; SAS Institute, 2003). Cow within parity was designated as a random effect in the model. The statistical model was $Y_{i j k m}=\mu+T_{i}+\operatorname{Per}_{j}+P_{m}+C(P)_{k(m)}+e_{i j k}$, where $Y_{i j k m}=$ dependent variable for the $i$ th treatment, $j$ th period, and $m$ th parity on the $k$ th cow within the $m$ th parity, $\mu=$ mean, $T_{i}=$ treatment effect $(i=1,2,3$, or 4), Per $_{j}=$ period effect $(j=1,2,3$, or 4$), P_{m}=$ parity effect ( $m=$ primiparous or multiparous), $C_{k(m)}=$ cow effect within parity, and $e_{i j k}=$ residual error. Parity effects and interaction terms were tested but not included in the model, as primary response variables were not significant. Data were deleted from 1 ruminally cannulated multiparous cow, as she was removed from the trial at the end of the first period. Two preplanned orthogonal contrasts (CON vs. DDGS, and linear effect of dietary wheat DDGS inclusion) were tested to examine the effects of feeding 3 sources of distillers grains to dairy cows. Significance was declared at $P \leq 0.05$, and a trend was reported if $0.05<P \leq 0.10$.

\section{RESULTS}

\section{Dietary Treatments}

Experimental diets were originally formulated to contain similar concentrations of nutrients. However, 
the actual calculated values from feed ingredients collected during the animal study showed that $\mathrm{CP}$ of all experimental diets averaged $20.5 \%$, which was greater than formulated values, and this is attributed in part to the greater CP concentration $(17.7 \pm 0.7 \%)$ for barley silage sampled during the collection periods (Table 2).

\section{DMI, Milk Yield, and Milk Composition}

Feeding the 3 sources of DDGS tended to increase DMI compared with the CON diet (Table 3). However, cows fed the DDGS diets had greater milk and ECM yields. Similarly, feeding the DDGS containing diets increased milk fat yield, lactose yield, and MUN concentration compared with those fed the CON diet. Cows fed the CON diet had greater milk protein concentration compared with those fed the DDGS-containing diets. As the dietary allocation of wheat DDGS increased, DMI increased linearly with no effect on milk production, which resulted in a linear decrease in feed efficiency. Increasing the dietary allocation of wheat DDGS had no effects on milk fat, protein, lactose, and MUN concentrations and yields.

\section{$B W, B C S$, and Estimated Energy Value of Experimental Diets}

Dietary treatments had no effect on BW, empty BW (EBW), BCS, and the changes in EBW and BCS (Table 4). However, the average BW and EBW were greater for multiparous cows compared with primiparous cows (691 vs. $591 \pm 15 \mathrm{~kg} ; P<0.001$ ), and (591 vs. $505 \pm 13 ; P<0.001)$, respectively. Neither $\mathrm{NE}_{\mathrm{M}}$ nor
EBW $\mathrm{NE}_{\mathrm{L}}$ was affected by dietary treatment, and they averaged $11.2 \pm 0.1 \mathrm{Mcal} / \mathrm{d}$ and $1.31 \pm 0.04 \mathrm{Mcal} / \mathrm{d}$, respectively. However, cows fed the DDGS diets had greater milk $\mathrm{NE}_{\mathrm{L}}$ output compared with the $\mathrm{CON}$ group, averaging 25.4 vs. $24.0 \pm 1.0 \mathrm{Mcal} / \mathrm{d}$, respectively. Consequently, total $\mathrm{NE}_{\mathrm{L}}$ output was greater for cows fed the DDGS-containing diets than those fed the CON diet by $4.4 \%$. Interestingly, the estimated diet $\mathrm{NE}_{\mathrm{L}}$ was linearly decreased as the dietary allocation of wheat DDGS increased in the diet, and cows fed the diet with wheat DDGS at $15 \%$ of DM had the lowest diet $\mathrm{NE}_{\mathrm{L}}$, averaging $1.48 \pm 0.06 \mathrm{Mcal} / \mathrm{kg}$ of DM. When compared with primiparous cows, multiparous cows had a greater $\mathrm{NE}_{\mathrm{M}}$ output (11.9 vs. $10.5 \pm 0.2 \mathrm{Mcal} / \mathrm{d}$; $P<0.001)$, and EBW gain $\mathrm{NE}_{\mathrm{L}}(1.42$ vs. $1.20 \pm 0.04 ; P$ $=0.002)$. However, multiparous cows had a lower diet $\mathrm{NE}_{\mathrm{L}}(1.46$ vs. $1.72 \pm 0.06 \mathrm{Mcal} / \mathrm{kg}$ of $\mathrm{DM} ; P=0.005)$ compared with primiparous cows.

\section{Plasma Glucose, Urea Nitrogen, Insulin, and Amino Acids}

Feeding the DDGS diets had no effect on plasma insulin or glucose concentrations when compared with the CON diet (Table 5). However, feeding increased levels of wheat DDGS tended to linearly decrease plasma glucose concentration. Consistent with the MUN data, plasma urea nitrogen was greater for cows fed the DDGS diets compared with those fed the control diet. However, feeding increased dietary wheat DDGS allocation linearly decreased plasma urea nitrogen.

Amino acid concentrations in plasma collected from the coccygeal vessel were similar across dietary

Table 3. Milk production and milk composition of cows fed wheat dried distillers grains with solubles (DDGS) at different dietary allocations

\begin{tabular}{|c|c|c|c|c|c|c|c|}
\hline \multirow[b]{2}{*}{ Item } & \multicolumn{4}{|c|}{ Dietary treatment ${ }^{1}$} & \multirow[b]{2}{*}{ SEM } & \multicolumn{2}{|c|}{ Contrast $(P \text {-value })^{2}$} \\
\hline & $\mathrm{CON}$ & WDG0 & WDG50 & WDG100 & & CON vs. DDGS & $\mathrm{L}$ \\
\hline $\mathrm{ECM},{ }^{3} \mathrm{~kg} / \mathrm{d}$ & 35.1 & 37.7 & 36.3 & 37.1 & 1.44 & 0.03 & 0.59 \\
\hline Feed efficiency ${ }^{4}$ & 1.56 & 1.62 & 1.57 & 1.45 & 0.07 & 0.82 & 0.01 \\
\hline Fat, \% & 3.57 & 3.54 & 3.71 & 3.53 & 0.10 & 0.75 & 0.94 \\
\hline Protein, $\mathrm{kg} / \mathrm{d}$ & 1.09 & 1.15 & 1.07 & 1.14 & 0.04 & 0.19 & 0.64 \\
\hline Lactose, \% & 4.51 & 4.55 & 4.55 & 4.57 & 0.04 & 0.06 & 0.40 \\
\hline Lactose, $\mathrm{kg} / \mathrm{d}$ & 1.58 & 1.72 & 1.62 & 1.69 & 0.07 & 0.01 & 0.54 \\
\hline MUN, mg/dL & 10.0 & 11.3 & 10.4 & 11.0 & 0.32 & 0.006 & 0.33 \\
\hline SCS & 2.77 & 2.80 & 2.67 & 2.61 & 0.24 & 0.42 & 0.11 \\
\hline
\end{tabular}

${ }^{1} \mathrm{CON}=$ control diet containing canola meal as the primary protein source; WDG0 = diet containing corn DDGS at $20 \%$ of diet DM; WDG50 $=$ diet containing 50\% corn DDGS and 50\% wheat DDGS; WDG100 = diet containing wheat DDGS at $15 \%$ of DM.

${ }^{2} \mathrm{CON}$ vs. DDGS = control vs. DDGS-containing diets; L = linear effect of dietary allocation of wheat DDGS.

${ }^{3} \mathrm{ECM}=[0.327 \times$ milk yield $(\mathrm{kg})]+[12.95 \times$ fat yield $(\mathrm{kg})]+[7.2 \times$ protein yield $(\mathrm{kg})]($ Orth, 1992).

${ }^{4}$ Feed efficiency $=$ ECM/DMI. 
Table 4. Body weight, empty BW (EBW), BCS, and net energy estimations for cows fed wheat dried distillers grains with solubles (DDGS) at different dietary allocations

\begin{tabular}{|c|c|c|c|c|c|c|c|}
\hline \multirow[b]{2}{*}{ Item } & \multicolumn{4}{|c|}{ Dietary treatment $^{1}$} & \multirow[b]{2}{*}{ SEM } & \multicolumn{2}{|c|}{ Contrast $(P \text {-value })^{2}$} \\
\hline & $\mathrm{CON}$ & WDG0 & WDG50 & WDG100 & & CON vs. DDGS & $\mathrm{L}$ \\
\hline $\mathrm{EBW}, \mathrm{kg}$ & 548 & 547 & 550 & 548 & 9.3 & 0.98 & 0.72 \\
\hline EBW change, $\mathrm{kg} / \mathrm{d}$ & 0.59 & 0.29 & 0.70 & 0.35 & 0.16 & 0.45 & 0.78 \\
\hline BCS & 3.00 & 2.99 & 2.96 & 2.99 & 0.07 & 0.56 & 0.99 \\
\hline BCS change/21 d & 0.05 & 0.03 & -0.02 & 0.05 & 0.04 & 0.61 & 0.78 \\
\hline $\mathrm{NE}_{\mathrm{M}},{ }^{4} \mathrm{Mcal} / \mathrm{d}$ & 11.2 & 11.2 & 11.2 & 11.2 & 0.1 & 0.99 & 0.70 \\
\hline $\mathrm{NE}_{\mathrm{L}}$ EBW change, ${ }^{5} \mathrm{Mcal} / \mathrm{d}$ & 1.29 & 1.33 & 1.30 & 1.33 & 0.04 & 0.45 & 0.86 \\
\hline Total $\mathrm{NE}_{\mathrm{L}},{ }^{6} \mathrm{Mcal} / \mathrm{d}$ & 36.2 & 38.2 & 37.2 & 38.0 & 1.0 & 0.02 & 0.76 \\
\hline Diet $\mathrm{NE}_{\mathrm{L}},{ }^{7} \mathrm{Mcal} / \mathrm{kg}$ & 1.62 & 1.65 & 1.61 & 1.48 & 0.06 & 0.47 & 0.01 \\
\hline
\end{tabular}

${ }^{1} \mathrm{CON}=$ control diet containing canola meal as the primary protein source; WDG0 = diet containing corn DDGS at 20\% of diet DM; WDG50 $=$ diet containing $50 \%$ corn DDGS and 50\% wheat DDGS; WDG100 = diet containing wheat DDGS at $15 \%$ of DM.

${ }^{2} \mathrm{CON}$ vs. DDGS $=$ control vs. DDGS-containing diets; $\mathrm{L}=$ linear effect of dietary allocation of wheat DDGS.

${ }^{3} \mathrm{NE}_{\mathrm{L}}(\mathrm{Mcal} / \mathrm{d})=$ milk yield $(\mathrm{kg}) \times(0.0929 \times$ fat $\%+0.0563 \times$ true protein $\%+0.0395 \times$ lactose $\% ; \mathrm{NRC}, 2001)$.

${ }^{4} \mathrm{NE}_{\mathrm{M}}(\mathrm{Mcal} / \mathrm{d})=0.08 \times \mathrm{BW}^{0.75}$.

${ }^{5} \mathrm{NE}_{\mathrm{L}}$ EBW change (Mcal/d) calculated according to NRC (2001).

${ }^{6}$ Total $\mathrm{NE}_{\mathrm{L}}(\mathrm{Mcal} / \mathrm{d})=\mathrm{NE}_{\mathrm{L}}+\mathrm{NE}_{\mathrm{M}}+\mathrm{NE}_{\mathrm{L}} \mathrm{EBW}$ change.

${ }^{7}$ Estimated diet $\mathrm{NE}_{\mathrm{L}}=$ total $\mathrm{NE}_{\mathrm{L}}$ output $(\mathrm{Mcal} / \mathrm{d}) / \mathrm{DMI}(\mathrm{kg} / \mathrm{d})$.

treatments (Table 6), except for the concentrations of Leu, Asn, and Gln. Concentrations of Leu decreased, whereas that of Gln increased linearly as the amount of wheat DDGS increased in the diets. Feeding the DDGS-containing diets decreased Asn concentration, whereas that of Gln tended to increase compared with the $\mathrm{CON}$ diet.

\section{Ruminal Fermentation and Total-Tract Apparent Digestibility}

Feeding the DDGS-containing diets had no effect on daily mean ruminal $\mathrm{pH}$, total VFA concentration, and the molar proportion of acetate, propionate, isobutyrate, valerate, and isovalerate when compared with the CON diet (Table 7). Nevertheless, cows fed the CON diet tended to have lower minimum ruminal $\mathrm{pH}$ compared with those fed the DDGS-containing diets. In ruminal fluid, the molar proportion of butyrate and ammonia and nitrogen concentration were greater for cows fed the DDGS-containing diets compared with the CON diet. In addition, increasing the dietary allocation of wheat DDGS resulted in a linear decrease in the molar proportion of butyrate and a linear increase in the ammonia nitrogen concentration.

Apparent total-tact digestibility of DM, OM, Starch, and NDF were not affected by dietary treatment (Table 8). However, feeding the DDGS diets tended to decrease the $\mathrm{CP}$ digestibility when compared with the CON diet.

\section{DISCUSSION}

The findings from this study indicated that feeding DDGS diets tended to increase DMI compared with the CON diet containing canola meal. Previous studies have reported no effect on DMI when feeding corn DDGS at approximately 20\% of DM (Anderson et al., 2006; Kleinschmit et al., 2006, Abdelqader et al.,

Table 5. Plasma metabolite concentrations of cows fed wheat dried distillers grains with solubles (DDGS) at different dietary allocations

\begin{tabular}{|c|c|c|c|c|c|c|c|}
\hline Plasma metabolite & \multicolumn{4}{|c|}{ Dietary treatment ${ }^{1}$} & SEM & \multicolumn{2}{|c|}{ Contrast $(P \text {-value })^{2}$} \\
\hline Glucose, $\mathrm{mg} / \mathrm{dL}$ & 61.3 & 62.2 & 61.4 & 60.6 & 0.83 & 0.90 & 0.06 \\
\hline Insulin, $\mu \mathrm{IU} / \mathrm{mL}$ & 9.2 & 8.9 & 7.9 & 8.8 & 1.12 & 0.51 & 0.89 \\
\hline
\end{tabular}


Table 6. Plasma AA concentrations of cows fed wheat dried distillers grains with solubles (DDGS) at different dietary allocations

\begin{tabular}{|c|c|c|c|c|c|c|c|}
\hline $\mathrm{AA}, \mu \mathrm{mol} / \mathrm{dL}$ & \multicolumn{4}{|c|}{ Dietary treatment $^{1}$} & SEM & \multicolumn{2}{|c|}{ Contrast $(P \text {-value })^{2}$} \\
\hline \multicolumn{8}{|l|}{ Essential AA } \\
\hline Met & 1.87 & 1.87 & 1.82 & 2.00 & 0.07 & 0.65 & 0.10 \\
\hline Lys & 5.04 & 5.10 & 4.84 & 5.62 & 0.41 & 0.72 & 0.29 \\
\hline Leu & 14.4 & 16.07 & 12.8 & 13.2 & 0.7 & 0.51 & 0.004 \\
\hline Thr & 6.53 & 6.09 & 6.40 & 6.44 & 0.27 & 0.33 & 0.22 \\
\hline $\operatorname{Trp}$ & 3.29 & 3.34 & 3.43 & 3.62 & 0.17 & 0.20 & 0.09 \\
\hline Phe & 4.28 & 4.44 & 4.17 & 4.46 & 0.12 & 0.52 & 0.91 \\
\hline Total essential AA & 70.9 & 73.0 & 67.8 & 72.1 & 3.10 & 0.97 & 0.80 \\
\hline \multicolumn{8}{|l|}{ Nonessential AA } \\
\hline Ala & 17.0 & 16.2 & 17.3 & 17.5 & 0.7 & 0.93 & 0.20 \\
\hline Gly & 21.51 & 22.05 & 23.44 & 22.26 & 1.66 & 0.24 & 0.85 \\
\hline Cit & 4.52 & 5.05 & 4.76 & 4.54 & 0.31 & 0.43 & 0.20 \\
\hline Tau & 4.24 & 4.18 & 4.38 & 4.33 & 0.17 & 0.69 & 0.42 \\
\hline Tyr & 5.90 & 6.36 & 5.83 & 6.22 & 0.33 & 0.33 & 0.65 \\
\hline Orn & 3.63 & 3.76 & 3.34 & 4.51 & 0.36 & 0.57 & 0.16 \\
\hline Total nonessential AA & 95.7 & 96.3 & 98.1 & 100.1 & 2.51 & 0.28 & 0.17 \\
\hline
\end{tabular}

${ }^{1} \mathrm{CON}=$ control diet containing canola meal as the primary protein source; WDG0 = diet containing corn DDGS at 20\% of diet DM; WDG50 $=$ diet containing 50\% corn DDGS and 50\% wheat DDGS; WDG100 = diet containing wheat DDGS at 15\% of DM.

${ }^{2} \mathrm{CON}$ vs. DDGS = control vs. DDGS-containing diets; $\mathrm{L}=$ linear effect of dietary allocation of wheat DDGS.

Table 7. Ruminal pH, VFA, and ammonia concentrations of cows fed wheat dried distillers grains with solubles (DDGS) at different dietary allocations

\begin{tabular}{|c|c|c|c|c|c|c|c|}
\hline \multirow[b]{2}{*}{ Item } & \multicolumn{4}{|c|}{ Dietary treatment ${ }^{1}$} & \multirow[b]{2}{*}{ SEM } & \multicolumn{2}{|c|}{ Contrast $(P \text {-value })^{2}$} \\
\hline & $\mathrm{CON}$ & WDG0 & WDG50 & WDG100 & & CON vs. DDGS & $\mathrm{L}$ \\
\hline \multicolumn{8}{|l|}{ Ruminal pH } \\
\hline Minimum & 5.49 & 5.53 & 5.68 & 5.51 & 0.13 & 0.09 & 0.68 \\
\hline Maximum & 6.78 & 6.79 & 6.80 & 6.77 & 0.04 & 0.88 & 0.77 \\
\hline Mean & 6.21 & 6.15 & 6.24 & 6.16 & 0.08 & 0.56 & 0.73 \\
\hline \multicolumn{8}{|l|}{ Ruminal $\mathrm{pH}<5.8$} \\
\hline $\mathrm{AUC} / \mathrm{kg}$ of DMI & 8.5 & 13.6 & 7.1 & 9.0 & 4.2 & 0.65 & 0.21 \\
\hline Total VFA, $\mathrm{m} M / \mathrm{L}$ & 157 & 153 & 161 & 155 & 4 & 0.81 & 0.74 \\
\hline Acetate (Ac), \% & 59.5 & 58.4 & 58.8 & 59.3 & 0.88 & 0.33 & 0.30 \\
\hline Propionate (Pr), \% & 23.2 & 22.3 & 23.3 & 23.0 & 0.76 & 0.70 & 0.48 \\
\hline Butyrate, $\%$ & 13.3 & 15.0 & 13.8 & 13.6 & 0.51 & 0.04 & 0.009 \\
\hline Isobutyrate, \% & 0.78 & 0.80 & 0.77 & 0.77 & 0.03 & 0.91 & 0.20 \\
\hline Valerate, $\%$ & 1.80 & 1.96 & 1.84 & 1.98 & 0.16 & 0.19 & 0.87 \\
\hline
\end{tabular}


Table 8. Total-tract apparent digestibility of cannulated cows fed wheat dried distillers grains with solubles (DDGS) at different dietary allocations

\begin{tabular}{|c|c|c|c|c|c|c|c|}
\hline Item $^{1}$ & \multicolumn{4}{|c|}{ Dietary treatment ${ }^{2}$} & SEM & \multicolumn{2}{|c|}{ Contrast $(P \text {-value })^{3}$} \\
\hline DMI. $\mathrm{kg} / \mathrm{d}$ & 20.7 & 20.3 & 23.0 & 24.3 & 1.7 & 0.36 & 0.11 \\
\hline OM intake, $\mathrm{kg} / \mathrm{d}$ & 18.8 & 18.9 & 21.0 & 22.4 & 1.6 & 0.30 & 0.15 \\
\hline OMD, $\%$ & 61.4 & 62.3 & 62.6 & 61.7 & 2.1 & 0.73 & 0.83 \\
\hline $\mathrm{CP}$ intake, $\mathrm{kg} / \mathrm{d}$ & 4.4 & 3.7 & 4.9 & 5.0 & 0.3 & 0.73 & 0.01 \\
\hline StarchD, \% & 88.9 & 92.0 & 89.2 & 90.1 & 1.2 & 0.18 & 0.16 \\
\hline NDF intake, $\mathrm{kg} / \mathrm{d}$ & 6.0 & 6.0 & 6.8 & 6.9 & 0.5 & 0.31 & 0.21 \\
\hline NDFD, \% & 43.5 & 45.6 & 45.4 & 43.1 & 3.3 & 0.74 & 0.57 \\
\hline
\end{tabular}

${ }^{1} \mathrm{DMD}=\mathrm{DM}$ digestibility; OMD = OM digestibility; $\mathrm{CPD}=\mathrm{CP}$ digestibility; StarchD = starch digestibility; NDFD = NDF digestibility. ${ }^{2} \mathrm{CON}=$ control diet containing canola meal as the primary protein source; WDG0 $=$ diet containing corn DDGS at $20 \%$ of diet DM; WDG50 $=$ diet containing $50 \%$ corn DDGS and 50\% wheat DDGS; WDG100 = diet containing wheat DDGS at $15 \%$ of DM.

${ }^{3} \mathrm{CON}$ vs. DDGS = control vs. DDGS-containing diets; L = linear effect of dietary allocation of wheat DDGS.

2009a). Similarly, replacing barley grain with wheat DDGS in the diets of beef steers (Gibb et al., 2008) and sheep (McKeown et al., 2010) did not affect DMI. Contrarily, Chibisa et al. (2010) reported a linear increase in DMI when canola meal was replaced with increasing concentrations of wheat DDGS in dairy cow diets. However, in the current study, replacement of corn DDGS with wheat DDGS resulted in a linear increase in DMI. Several factors can influence DMI in lactating dairy cows, including physical and chemical characteristics of diets, physiological status of the cow, and environmental stressors (Allen, 2000). Factors such as ruminal $\mathrm{pH}$ and production of VFA are known to affect the DMI of dairy cows, and excess fermentation of readily available starch could exceed the buffering and absorptive capacity in the rumen, decreasing ruminal pH and DMI (Nocek, 1997). However, in the current study, dietary treatments had no effect on ruminal $\mathrm{pH}$ and total VFA concentrations. Although the cause for greater DMI for cows fed more wheat DDGS cannot be identified, our findings are similar to those of Walter et al. (2010), who showed that feeding wheat DDGS at 20 and $40 \%$ of DM in replacement of barley grain resulted in a linear increase in DMI. However, the linear increase in DMI with no effect on milk yield resulted in a linear decrease in feed efficiency as the dietary allocation of wheat DDGS increased in the diets.

The greater feed efficiency for cows fed more corn DDGS relative to wheat DDGS might indicate differences in protein quality and energy availability from these diets to support milk production. Although DDGS is well recognized as an excellent source of energy, attributed to their high concentration of readily digestible NDF and fat (Schingoethe et al., 2009), the energy content varies depending on nutrient digestibility. Nuez
Ortín and Yu (2009) have indicated that wheat DDGS had a greater truly digested NFC (201 vs. $85 \mathrm{~g} / \mathrm{kg}$ of $\mathrm{DM}$ ) and CP (386 vs. $312 \mathrm{~g} / \mathrm{kg}$ of DM), but lower values for truly digested FA (40 vs. $155 \mathrm{~g} / \mathrm{kg}$ of DM) and NDF (115 vs. $221 \mathrm{~g} / \mathrm{kg}$ of DM) compared with corn DDGS. The authors have also indicated that wheat DDGS had lower energy values for $\mathrm{NE}_{\mathrm{L} 3 \times}\left(\mathrm{NE}_{\mathrm{L}}\right.$ at $3 \times$ maintenance) compared with corn DDGS: $\mathrm{NE}_{\mathrm{L} 3 \times}$ was 1.94 and $2.35 \mathrm{Mcal} / \mathrm{kg}$, respectively for wheat DDGS and corn DDGS. These values were similar to those obtained from the current study, where the predicted $\mathrm{NE}_{\mathrm{L}}$ was 1.95 and $2.10 \mathrm{Mcal} / \mathrm{kg}$ for wheat DDGS and corn DDGS, respectively (NRC, 2001). Additionally, the predicted $\mathrm{NE}_{\mathrm{L}}$ was linearly decreased as the concentrations of wheat DDGS increased in the diet. These findings might partly explain the similar response in milk production with greater DMI when cows fed more wheat DDGS in place of corn DDGS, resulting in lower values for feed efficiency (Casper, 2008). Nevertheless, feed efficiency data from the current study need to be interpreted with caution, as it was measured over short periods (i.e., $21 \mathrm{~d}$ ) and temporary feed efficiency can be affected by mobilization of body energy.

In the present study, feeding the DDGS-containing diets resulted in an average increase of $5.6 \%$ in milk production compared with the CON diet. Previous research indicated that feeding corn DDGS at approximately $20 \%$ of dietary DM increased (Leonardi et al., 2005; Anderson et al., 2006; Kleinschmit et al., 2006) or had no effect on milk production (Hippen et al., 2004; Abdelqader et al., 2009a). Similar results have been observed when wheat DDGS was fed as a partial replacement of barley silage (Zhang et al., 2010b). Chibisa et al. (2010) reported a quadratic response in milk yield $(42.8,42.2,43.6$, and $40.5 \mathrm{~kg} / \mathrm{d})$ when wheat DDGS 
was fed at increasing concentrations of diet DM at 0 , 10,15 , and $20 \%$ in place of canola meal. The improvement in milk production may indicate an improvement in energy and protein supply to the mammary gland, and thus support the needs for milk protein and lactose synthesis.

Depression in milk fat concentration is a major concern when dietary allocation of DDGS increases, particularly for corn DDGS because of the greater fat content compared with wheat DDGS. Previous research reported that feeding corn DDGS up to $20 \%$ of dietary DM had no effect on milk fat concentration (Anderson et al., 2006; Kleinschmit et al., 2006). In contrast, Leonardi et al. (2005) reported that milk fat concentration decreased linearly when corn DDGS was fed in place of soybean meal at increasing concentrations up to $15 \%$ of dietary DM. Abdelqader et al. (2009a) indicated that feeding corn DDGS at $30 \%$ of dietary DM decreased milk fat concentration compared with a control diet containing soybean meal, and concluded that DDGS may contain small concentrations of free oil that are more readily available in the rumen, thus interfering with fermentation and biohydrogenation. Schingoethe et al. (2009) indicated that sufficient forage fiber must be included in DDGS-containing diets to avoid depression in milk fat content. The importance of forage fiber in minimizing the effect of DDGS on milk fat content was clearly demonstrated by Zhang et al. (2010a) when replacing barley silage with wheat DDGS caused a decrease in milk fat content. Although dietary forage NDF content was $17.8 \%$ DM in the present study, milk fat concentration was not affected by dietary treatment. The increase in milk fat yield when cows were fed the DDGS-containing diets can be attributed to the increase in milk production compared with those fed the CON diet. Due to the lower fat content in wheat DDGS, milk fat depression might not be a major concern as long as sufficient forage NDF is provided in diets of lactating dairy cows.

In DDGS-containing diets, Lys is likely the firstlimiting AA, which might limit milk protein synthesis (Nichols et al., 1998). In the current study, the calculated concentration of Lys as percentage of MP was numerically lower for DDGS-containing diets compared with the CON diet (NRC, 2001). This variation in Lys content might explain the greater milk protein concentration for cows fed the CON diet compared with those fed the DDGS diets, although we did not observe lower plasma Lys concentration for cows fed the DDGS diets compared with the CON diet in the current study. A similar finding has been reported when wet corn distillers grains (Schingoethe et al., 1999) was fed in dairy cow diets replacing soybean meal and part of the rolled corn. Kleinschmit et al., (2006) reported a decrease in milk protein percentage when 3 sources of corn DDGS where fed in place of soybean meal.

The increase in MUN and plasma urea nitrogen in cows fed the DDGS-containing diets could be attributed partially to the greater urea concentration in these diets, which was included to balance for diets RDP content. However, if Lys was the first-limiting AA in these diets, then any excess of essential AA would not be utilized in the mammary gland for protein synthesis; thus, any excess nitrogen would be converted to ammonia and excreted in the form of urea in the body fluids such as plasma, urine, and milk. In agreement with our findings, Abdelqader et al. (2009a) reported an increase in MUN concentrations for cows fed a corn DDGS diet compared with the control diet containing soybean meal. Contrarily, MUN has been reported to decrease when feeding corn DDGS in place of soybean meal (Anderson et al., 2006; Kleinschmit et al., 2006) or wheat DDGS in partial replacement of barley silage (Zhang et al., 2010a). These inconsistencies could be attributed to differences in RDP, RUP, degradation rate, as well as, AA composition of the protein sources used in each study.

The increase in ruminal ammonia nitrogen concentration when cows were fed the DDGS-containing diet can be partially attributed to differences in RDP concentrations between corn and wheat DDGS. Although the diets were originally formulated to have similar $\mathrm{CP}$, RDP, and RUP contents, diets containing wheat DDGS had greater CP contents, which may explain greater ammonia nitrogen concentration in the rumen for diets containing wheat DDGS. Excretion of excess ammonia in the form of urea is an energy-consuming process. Therefore, the greater RDP values of wheat DDGS compared with corn DDGS might be attributed to excess urea synthesis, which can affect the feeding efficiency of wheat DDGS. Nuez-Ortín and Yu (2010) reported that the $\mathrm{CP}$ content of DDGS produced from mixtures of wheat and corn increased as the proportion of wheat increased in the feedstock. However, the RUP fraction increased as the proportion of corn increased in the feedstock, and the RDP fraction increased as the content of wheat in the feedstock increased. Obviously, these findings suggest that RDP concentrations might increase when more wheat DDGS in place of corn DDGS is included in dairy cow diet, resulting in an increase in ruminal ammonia concentration.

The DDGS evaluated in the current study was not only produced from different type of grain, but also produced by different ethanol plants. Nutrient variability among and within DDGS sources is a major contributor to the variable results obtained from DDGS research 
studies. Variations in DDGS composition can be due to different feedstock and processing conditions used in ethanol production. Spiehs et al. (2002) indicated that variations in DDGS nutrient composition can be attributed to grain crop used, percentage of solubles added back to the dried distillers grains, and the extent of fermentation process. Nevertheless, nutrient variation has also been reported within the same ethanol plants (Belyea et al., 2004). As such, when DDGS are used as the primary protein source, it is important not to rely on book values for nutrient composition, but to obtain actual nutrition composition data before formulation of diets.

\section{CONCLUSIONS}

Feeding wheat-based DDGS up to $15 \%$ DM can improve milk production compared with canola meal without negatively affecting milk component yields. Results from this study indicated that replacing corn DDGS with wheat DDGS might not affect milk production in spite of reduction in feed efficiency. Feeding wheat DDGS up to $15 \%$ of dietary DM had no negative effect on ruminal fermentation and apparent total-tract digestibility. Also, wheat-based DDGS or a mixture of corn DDGS and wheat DDGS can be used effectively in dairy cow rations without negatively affecting dairy cow production.

\section{REFERENCES}

Abdelqader, M. M., A. R. Hippen, K. F. Kalscheur, D. J. Schingoethe, and A. D. Garcia. 2009a. Isolipidic additions of fat from corn germ, corn distillers grains, or corn oil in dairy cow diets. J. Dairy Sci. 92:5523-5533.

Abdelqader, M. M., A. R. Hippen, D. J. Schingoethe, K. F. Kalscheur, K. Karges, and M. L. Gibson. 2009b. Evaluation of corn germ from ethanol production as an alternative fat source in dairy cow diets. J. Dairy Sci. 92:1023-1037.

Al-Suwaiegh, S., K. C. Fanning, R. J. Grant, C. T. Milton, and T. J. Klopfenstein. 2002. Utilization of distillers grains from the fermentation of sorghum or corn in diets for finishing beef and lactating dairy cattle. J. Anim. Sci. 80:1105-1111.

Aldai, N., J. L. Aalhus, M. E. R. Dugan, W. M. Robertson, T. A. McAllister, L. J. Walter, and J. J. McKinnon. 2010. Comparison of wheat- versus corn-based dried distillers' grains with solubles on meat quality of feedlot cattle. Meat Sci. 84:569-577.

Allen, M. S. 2000. Effects of diet on short-term regulation of feed intake by lactating dairy cattle. J. Dairy Sci. 83:1598-1624.

Anderson, J. L., D. J. Schingoethe, K. F. Kalscheur, and A. R. Hippen. 2006. Evaluation of dried and wet distillers grains included at two concentrations in the diets of lactating dairy cows. J. Dairy Sci. 89:3133-3142.

AOAC. 2002. Official Methods of Analysis. 17th ed. Association of Official Analytical Chemists, Gaithersburg, MD.

Belyea, R. L., K. D. Rausch, and M. E. Tumbleson. 2004. Composition of corn and distillers dried grains with solubles from dry grind ethanol processing. Bioresour. Technol. 94:293-298.

Boila, R. J., and R. J. Ingalls. 1994. The ruminal degradation of dry matter, nitrogen and amino acids in wheat-based distillers' grains in sacco. Anim. Feed Sci. Technol. 48:57-72.
Cao, Z. J., J. L. Anderson, and K. F. Kalscheur. 2009. Ruminal degradation and intestinal digestibility of dried or wet distillers grains with increasing concentrations of condensed distillers solubles. J. Anim. Sci. 87:3013-3019.

Casper, D. P. 2008. Factors affecting feed efficiency of dairy cows. Pages 133-144 in Proc. Tri-State Dairy Nutr. Conf. Fort Wayne, IN.

Chibisa, G. E., D. A. Christensen, and T. Mutsvangwa. 2010. Effect of replacing canola meal with wheat-based dried distillers grains with solubles on ruminal fermentation, microbial nitrogen supply and milk production in dairy cows. J. Dairy Sci. 93(Suppl. 1):576. (Abstr.)

Cochran, R. C., D. C. Adams, J. D. Wallace, and M. L. Galyean. 1986. Predicting digestibility of different diets with internal markers: Evaluation of four potential markers. J. Anim. Sci. 63:1476-1483.

Fawcett, J. K., and J. E. Scott. 1960. A rapid and precise method for the determination of urea. J. Clin. Pathol. 13:156-159.

Firkins, J. L., L. L. Berger, G. C. Fahey Jr., and N. R. Merchen. 1984. Ruminal nitrogen degradability and escape of wet and dry distillers grains and wet and dry corn gluten feeds. J. Dairy Sci. 67:1936-1944.

Gibb, D. J., X. Hao, and T. A. McAllister. 2008. Effect of dried distillers' grains from wheat on diet digestibility and performance of feedlot cattle. Can. J. Anim. Sci. 88:659-665.

Hippen, A. R., K. F. Kalscheur, D. J. Schingoethe, and A. D. Garcia. 2004. Increasing inclusion of dried corn distillers grains in dairy cow diets. J. Dairy Sci. 87(Suppl. 1):1965 (Abstr.)

Ingalls, J. R. 1995. The ruminal and post-ruminal in situ digestion of dry matter, nitrogen, and amino acids in wheat-based dried distillers grains. Proc. Distillers Feed Research Council 50:55-65.

Karkalas, J. J. 1985. An improved enzymatic method for determination of native and modified starch. J. Sci. Food Agric. 36:1019-1027.

Khorasani, G. R., E. K. Okine, and J. J. Kennelly. 1996. Forage source alters nutrient supply to the intestine without influencing milk yield. J. Dairy Sci. 79:862-872.

Kim, B. G., M. D. Lindemann, M. Rademacher, J. J. Brennan, and G. L. Cromwell. 2006. Efficacy of DL-methionine hydroxy analog free acid and DL-methionine as methionine sources for pigs. J. Anim. Sci. 84:104-111.

Kleinschmit, D. H., J. L. Anderson, D. J. Schingoethe, K. F. Kalscheur, and A. R. Hippen. 2007. Ruminal and intestinal degradability of distillers grains plus solubles varies by source. J. Dairy Sci. 90:2909-2918.

Kleinschmit, D. H., D. J. Schingoethe, K. F. Kalscheur, and A. R. Hippen. 2006. Evaluation of various sources of corn dried distillers grains plus solubles for lactating dairy cattle. J. Dairy Sci. 89:4784-4794.

Leonardi, C., F. Giannico, and L. E. Armentano. 2005. Effect of water addition on selective consumption (sorting) of dry diets by dairy cattle. J. Dairy Sci. 88:1043-1049.

McKeown, L. E., A. V. Chaves, M. Oba, M. E. R. Dugan, E. Okine, and T. A. McAllister. 2010. Effects of corn-, wheat- or triticale-based distillers grains with solubles on in vitro fermentation, growth performance and carcass traits of lambs. Can. J. Anim. Sci. 90:99-108.

Mustafa, A., J. J. McKinnon, and D. A. Christensen. 2000. The nutritive value of thin stillage and wet distillers' grains for ruminants. Asian-australas. J. Anim. Sci. 13:1609-1618.

NRC. 2001. Nutrient Requirements of Dairy Cattle. 7th ed. National Academy Press, Washington, DC.

Nichols, J. R., D. J. Schingoethe, H. A. Maiga, M. J. Brouk, and M. S. Piepenbrink. 1998. Evaluation of corn distillers grains and ruminally protected lysine and methionine for lactating dairy cows. J. Dairy Sci. 81:482-491.

Nocek, J. E. 1997. Bovine acidosis: Implications on laminitis. J. Dairy Sci. 80:1005-1028.

Nuez Ortín, W. G., and P. Yu. 2009. Nutrient variation and availability of wheat DDGS, corn DDGS and blend DDGS from bioethanol plants. J. Sci. Food Agric. 89:1754-1761.

Nuez-Ortín, W. G., and P. Yu. 2010. Estimation of ruminal and intestinal digestion profiles, hourly effective degradation ratio and po- 
tential $\mathrm{N}$ to energy synchronization of co-products from bioethanol processing. J. Sci. Food Agric. 90:2058-2067.

Orth, R. 1992. Sample Day and Lactation Report. DHIA 200 Fact Sheet A-2. Mid-States Dairy Records Processing Center (DRPC), Ames, IA.

Penner, G. B., K. A. Beauchemin, and T. Mutsvangwa. 2006. An evaluation of the accuracy and precision of a stand-alone submersible continuous ruminal $\mathrm{pH}$ measurement system. J. Dairy Sci. 89:2132-2140.

Penner, G. B., P. Yu, and D. A. Christensen. 2009. Effect of replacing forage or concentrate with wet or dry distillers' grains on the productivity and chewing activity of dairy cattle. Anim. Feed Sci. Technol. 153:1-10.

Powers, W. J., H. H. Van Horn, B. Harris Jr., and C. J. Wilcox. 1995. Effects of variable sources of distillers dried grains plus solubles on milk yield and composition. J. Dairy Sci. 78:388-396.

SAS Institute. 2003. SAS User's Guide: Statistics. Version 9.1. SAS Inst. Inc., Cary, NC.

Schingoethe, D. J., M. J. Brouk, and C. P. Birkelo. 1999. Milk production and composition from cows fed wet corn distillers grains. J. Dairy Sci. 82:574-580

Schingoethe, D. J., K. F. Kalscheur, A. R. Hippen, and A. D. Garcia. 2009. Invited review: The use of distillers products in dairy cattle diets. J. Dairy Sci. 92:5802-5813.
Spiehs, M. J., M. H. Whitney, and G. C. Shurson. 2002. Nutrient data base for distillers dried grains with solubles produced from new generation ethanol plants in Minnesota and South Dakota. J. Anim. Sci. 80:2639-2645.

Van Soest, P. J., J. B. Robertson, and B. A. Lewis. 1991. Methods for dietary fiber, neutral detergent fiber, and nonstarch polysaccharides in relation to animal nutrition. J. Dairy Sci. 74:3583-3597.

Walter, L. J., J. L. Aalhus, W. M. Robertson, T. A. McAllister, D. J. Gibb, M. E. R. Dugan, and J. J. McKinnon. 2010. Evaluation of wheat or corn dried distillers' grains with solubles on performance and carcass characteristics of feedlot steers. Can. J. Anim. Sci 90:259-269.

Zhang, S. Z., G. B. Penner, M. M. Abdelqader, and M. Oba. 2010a Effect of feeding alfalfa hay on chewing, rumen $\mathrm{pH}$, and milk fat concentration of dairy cows fed wheat dried distillers grains with solubles as a partial replacement of barley silage. J. Dairy Sci. 93:3243-3252

Zhang, S. Z., G. B. Penner, W. Z. Yang, and M. Oba. 2010b. Effects of partially replacing barley silage or barley grain with dried distillers grains with solubles on rumen fermentation and milk production of lactating dairy cows. J. Dairy Sci. 93:3231-3242. 